\title{
Fiscal council: European model or new global standard?
}

\author{
András Bethlendi \\ Department of Finance, Faculty of Economic and Social Sciences \\ Budapest University of Technology and Economics \\ Hungary \\ betblendi@finance.bme.bu
}

\section{Csaba Lentner}

Faculty of Science of Public Governance and Administration

National University of Public Service

Hungary

Lentner.Csaba@uni-nke.hu

\section{László Vasa}

Management Campus, Széchenyi István University

Hungary

vasa.laszlo@sze.hu

\section{András Póra}

Department of Finance, Faculty of Economic and Social Sciences

Budapest University of Technology and Economics

Hungary

pora@finance.bme.bu

Abstract. The great recession of 2008 caused fiscal crises in several countries. This phenomenon highlighted the relevance of the problem of fiscal alcoholism and excessive sovereign debt. Nowadays rules-based fiscal policies have become more and more widespread to limit indebtedness. This article explores one of the most important elements of rules-based systems: the fiscal council. The key question imposed was: is it mostly a European phenomenon, or rather a global standard? As a method, we employed descriptive statistics, then a hierarchical cluster analysis, based on the data of the IMF Fiscal Council Dataset. In conclusion, two

Received: May, 2019

1st Revision: August, 2019

Accepted:

November, 2019 $10.14254 / 2071-$ separated groups were formed: an EU and a non-EU cluster with some outliers, thus our working hypothesis was underpinned. Our results have thus contributed to the literature and advanced the case that in the last ten years the increased number of fiscal councils can be attributed to international (European) 
regulations or internal political issues rather than actual enhancements of fiscal prudence.

Keywords: sovereign debt, rules-based fiscal policy, fiscal council, independent fiscal institutions, fiscal prudence

JEL Classification: E02, E62, F34, F36, H30, H60, H61, H63, H68, H87, P16, P41, P43, P50

\section{INTRODUCTION}

In numerous countries, the 2008 global crisis turned into a fiscal crisis that further increased the significance of the excessive indebtedness problem. This gave additional impetus to the spread of the rulesbased budgeting method since heavily indebted countries consider it as the main vehicle for easing equilibrium tensions. In the European Union, and more specifically in the EMU, this is a particularly important and not a new question, as the grave budgetary problems of certain euro area members also jeopardize the stability of the common currency, the euro. Already back in the late 1990s and early 2000s, during the reform of the Stability and Growth Pact, rule-based budgeting as a solution was surrounded by heated professional arguments. Rules were also adopted on the deficit and on sovereign debt at the level of the European Union. Simultaneously, national regulations were adopted in numerous countries. The question of fiscal discipline has become a still more difficult challenge in the new, transitioning EU member states following the 2008 crisis (Jiroudková et al., 2015).

After the crisis there was an increase in the gross debt position in the emerging market and middleincome economies (IMF, 2018). Even among the advanced economies, only the Euro area has been able to enhance its position regarding gross debt in recent years due to the strict policy mix applied.

In the case of rules-based budgeting, the key fiscal rules (fiscal policy limits) are codified in laws - and even, occasionally, in the constitution - in the form of numerical rules, with determined procedures and institutionalized control. In practice, this involves the application of a combination of the following elements:

- budget policy rules (e.g. the adoption of expenditure caps in the interest of maintaining equilibrium),

- budget procedure rules (e.g. the adoption of medium-term budget planning),

- transparency standards (e.g. the application of accrual-based accounting),

- institutional guarantees have been put in place in the interests of transparency and to comply with the rules, and these guarantees are supervised from both the macro- and micro-economic perspectives:

- On a micro-economic level, public finance control includes the internal control systems of budgetary institutions, the governmental supervisory body, and the audit office/court of auditors of the given country.

- On a macro-economic level, public finances are controlled by the audit office/court of auditors of the given country, an organization independent of the government and/or the fiscal council. In addition, the activities of independent central banks are also included, since they analyse and publicly assess budgetary developments.

The above elements fundamentally developed in parallel, and as these institutions mutually reinforce each other, they can reduce budgetary risks. The consistent application of the rules-based system is expected 
to reverse the trend that has manifested in the past few decades in the form of excessive budget spending, budget unsustainability and an increase in sovereign debt.

This study tackles a relatively new element of the fiscal supervision of public finances within the abovementioned set of instruments: the institution of the fiscal council. The fundamental question of our study is whether fiscal councils can be considered as a basically European model or whether what we are witnessing is the evolution of a global standard.

Our study is structured as follows. A brief description is given of the economic policy experiences and changes in attitude that led to the establishment of fiscal councils, and the literature relevant to this topic is summarized. Then fiscal councils are classified according to their various characteristics, on the basis of the IMF's Fiscal Council Dataset. In addition to descriptive statistics, a cluster analysis is applied. Then conclusions are provided for the study.

\section{THE RISE OF THE INDEPENDENT FISCAL INSTITUTION}

Rules-based fiscal policy was adopted with the intention of correcting the shortcomings of discretional fiscal policy. Theoretically, discretional fiscal stabilization is supposed to operate counter-cyclically: in bad times, a budget deficit is used to stabilize the economy, while in good times there is a surplus. Numerous empirical studies (e.g. Gersl et al., 2014, Gilbert-De Jong, 2017) have demonstrated that, in practice, discretional fiscal policy often has pro-cyclical effects contrary to the objectives, especially in developing countries.

The European sovereign crisis that followed the 2008 crisis shed light on the fact that rules-based fiscal policy, which contains an explicit rule on the current deficit and the debt limit (adopted by the Stability and Growth Pact at the European Union level), is insufficient in itself. Several reasons are given for this by the authors Calmfors and Wren-Lewis (2011). One of the simplest cases is when rules are plainly not observed (Greece). Another case is when the deficit caps are respected but are so close that practically no elbowroom is left in the budget for any contingencies and income foregone (Portugal, France and the United Kingdom).

Other countries were overly optimistic about the sustainability of the economic upturn, and when it ended the budget position underwent a massive deterioration (Ireland, Spain and the United Kingdom). On the whole, the politically motivated propensity to generate deficits, the excessive optimism characteristic of planning and the consequential pro-cyclicality typically lead to unsustainable fiscal developments, which is a fundamental economic policy problem.

The above-mentioned phenomena were exacerbated by the crisis, and it became broadly clear that fiscal rules alone are insufficient, as they cannot ensure fiscal discipline and its sustainability. For this reason, experts started to look for new methods to enforce budgetary discipline. Extensive attention was paid to the establishment and reinforcement of independent fiscal institutions (IFI).

In articulating the problem, certain authors go as far as to state that there is no efficient way to enforce compliance with these rules while fiscal decisions remain in the hands of elected political decision makers. They make a comparison with central banks (Larch and Braendle, 2018), declaring that just as elected political representatives cannot be allowed to manage monetary policy (price stability), fiscal developments also need external control in the form of an independent institution. They argued that the two main macroeconomic policies diverged considerably: from the late 1980s monetary policy was assigned to central banks, independent of governments, while fiscal stability remained in the hands of politicians, albeit to a more limited extent as a result of the strengthening of rules-based fiscal policies.

There is nothing new in this idea, as several renowned economists (Blinder, 1997 and Fischer, 1995) had already raised it in the mid-1990s. However, in the absence of political support, it did not seem to be a viable idea. In a European context, it was raised as a specific proposal in the early 2000s. Already at that 
time, Wyplosz (2002) predicted that rules-based budgets would never solve the fundamental economic policy problem and the consequent inclination to generate a deficit. He proposed that every Member State should be required to set up a fiscal policy committee independent of the government, under the control of people with the appropriate professional background, and with a mandate to maintain the sovereign debt over the medium term. Larch and Braendle (2018) also considered it logical to take fiscal macro-economic stability policy out of the hands of elected national governments.

The concept was that independent fiscal institutions would determine the target deficit and the maximum allowed sovereign debt for the particular year. Elected politicians would be left with elbowroom to determine the structure of fiscal revenues and expenditures while observing the target deficit for the year. Short-term fiscal policy distortions could thus be eliminated. Using the classification of Musgrave (1959), the stability function of fiscal policy would, therefore, be separated from its distributive and allocation functions. An additional argument regarding the euro area is that a better coordinated fiscal stabilization policy would facilitate further economic and monetary integration, and could also increase the efficiency of the euro area's centralized monetary policy.

The experiences of the 2011-2012 sovereign crisis in Europe, especially as sovereign debts highly correlate with the banking sector's debts, rekindled debates about a possible future fiscal union of the EU. With the 2012 establishment of the European Stability Mechanism (ESM), one of the institutions of common crisis management was implemented. After the crisis, the EU made great efforts to implement a banking union based on two pillars: The Single Supervisory Mechanism (SSM) and the Single Resolution Mechanism (SRM). The establishment of a single capital market is planned for 2019 and it is an important step, perhaps also towards fiscal integration.

The initial, simple EU-level fiscal rules included in the Stability and Growth Pact have gradually been completed. Additions include, for example, the two amendments to the Stability and Growth Pact, and the "Treaty on Stability, Coordination and Governance" (TSCG), in force since 2013, which contains new and more detailed provisions on the national limitation of fiscal policy discretion and on increasing EU-level fiscal co-ordination. In 2011, all Member States of the EU was officially requested to set up IFIs.

The European Fiscal Board (EFB), which was established in 2015, is an independent body of the European Commission. It was set up for a fundamentally advisory function, and it assists the Commission in performing its multi-lateral fiscal supervisory functions for the euro area. Its main responsibilities are the following:

1. It provides an ex-post evaluation of the implementation of the EU's fiscal framework and of the appropriateness of the current fiscal stance in the euro area and on a national level;

2. It provides an ex-ante assessment of the prospective fiscal stance of the entire euro area. The Stability and Growth Pact focuses on national budgets and does not determine the aggregated fiscal stance. For this reason, the Fiscal Board must contribute to the assessment of the general effects of the euro area and national fiscal stances, while respecting the provisions of the Stability and Growth Pact.

3. If in the course of the above, it establishes that fiscal risks are jeopardizing the operation of the EMU, it may give advice on the appropriate policy stance.

4. It co-operates with the national fiscal councils in both methodologies and in the joint interpretation of matters related to the European Union's fiscal framework.

5. It may make proposals to the Commission.

It is clear from points 1-3 above that the EFB's duty is to provide an independent evaluation of the fiscal processes all over Europe and more specifically in the entire euro area. In this sense, this institution can already be considered to be a preliminary institution of fiscal union. 
The European Commission makes considerable efforts to promote fiscal union and Acharya and Steffen (2017) and others believe that the three unions are interrelated, as there can be no single government securities market without a fiscal union. The literature specifies the following elements of a fiscal union (Thirion, 2017):

1. A crisis management mechanism;

2. Rules, co-ordination and monitoring;

3. A common guarantee for sovereign debts; and

4. Insurance and stabilization.

Although still in their infancy, most of these four elements are already recognizable in the fiscal system of the EU. The IMF material is consistent with the EU's intentions: Berger, Dell'Ariccia and Obstfeld (2018) think that without at least some degree of fiscal union, the EU will face existential risks and, for this reason, at least some kind of simplified fiscal union will be needed following the earliest possible completion of the banking union and capital market union. However, there are sceptics as well: according to Herzog (2018), even if the EU Commission thinks that without a supranational fiscal capacity the EMU will fail, it is not really feasible because of the resistance of the member states. Therefore, it would be better to "stick to and enhance the rule-based architecture of Maastricht" (Herzog, 2018).

The most recent development is the June 2018 Meseberg Declaration, a German-French proposal envisaging a potential reform procedure including the following actions of fiscal relevance:

1. A separate budget for the EU, which would use funds raised from payments by the Member States, from funds provided by the European Union and from independent sources, e.g. revenues from taxes on financial transactions, and would be managed by a separate organization;

2. Development of the ESM towards a European Monetary Fund (following the IMF's example);

3. The potential setting up a European Unemployment Stabilization Fund.

That said, a fiscal policy function independent of governments is not yet a political reality. For this reason, the fiscal councils that have been established so far have the following competencies: forecasting, analysis, evaluation and consultation. A few countries have had independent institutions with fiscal control functions for a long time, actually for several decades. These include the Central Planning Bureau of the Netherlands, the Economic Council of Denmark and the High Council of Finance in Belgium. All of them are intended to supervise the discretional fiscal policies of the incumbent governments (watchdog function).

The IMF (2013) recommended a more distinct differentiation between the above two groups, but at the same time the literature frequently confuses the two: 1) independent fiscal institutions with a clearly defined mandate and guaranteed independence (such as central banks); 2) soft institutions with a function to influence and convince, these are called fiscal councils.

It must be highlighted that the US-model (a Budget Office working closely with the legislature) was adopted by some countries. Such cases include Canada and Mexico (which neighbour the US), Australia and South Africa (with a common cultural and legal heritage) and, finally, South Korea. The later adopted its system gradually after the Asian sovereign crisis of 1998.

\section{CLASSIFICATION OF FISCAL COUNCILS}

Fiscal councils may have the following duties:

1. Ex-post evaluation of whether fiscal policy achieved its set objectives in the past; 
2. Ex-ante evaluation of whether fiscal policy can be expected to achieve its set objectives in the future;

3. Analysis of the long-term sustainability of fiscal policy;

4. Analysis of fiscal transparency;

5. Measuring the costs of government policy initiatives;

6. Macro-economic forecasts;

7. Normative fiscal policy proposals.

IFIs have a highly heterogeneous practice. In some countries, IFIs have mandates exceeding the central government and covering all the other government sectors: decentralized agencies, local governments and state-owned companies. Consequently, IFIs have very different sizes: examples range from IFIs composed of a few persons (exclusively economists) to supervisory bodies with staffs of several hundred. The latter is already fundamentally engaged in ex-post supervision and can be classified among audit offices/courts of auditors. IFIs are, fundamentally, fiscal institutions that perform an ex-ante assessment, while ex-post evaluation is essentially conducted by courts of auditors (Kopits, 2016). The OECD summed up IFI good practices in one of their recommendations (OECD, 2014). Simultaneously, the IMF also developed its recommendations (IMF 2013).

IFIs can be considered as a supplement to rules-based budgeting. These two institutions can reinforce each other's operation in several ways. IFI's may be of assistance in the assessment of the probability of compliance with the rules. They may even make proposals for the extraordinary events that justify dispensing with the observation of simple rules or for the improvement of rules. In practice, this constitutes a highly complex activity, as the cyclical effects and the fiscal impacts of various external shocks must also be taken into consideration. The advisory character of IFIs is important because there is no consensus in either the academic literature or among economic policy analysts about long-term fiscal objectives. Conflicts between governments and IFIs is natural, and this is why it is important to ensure that - similarly to central banks - IFIs can resist political pressure. (Calmfors and Wren-Lewis, 2011).

At the same time, Gersl et al. (2014) point out that, although in general the establishment of an independent fiscal council is a desirable institutional change, if the new agency is weak in predicting shocks, this institutional change does not necessarily bring about an improvement in welfare.

The majority of the authors engaged in this topic (Debrun and Kumar, 2007; IMF, 2013; Kopits, 2016 and Beetsma and Debrun, 2016) describe fiscal council operation and structure as highly heterogeneous. This study will demonstrate that, in fact, there are relatively homogeneous groups of fiscal councils.

We examine the different underlying causes of the formation of these groups. Based on this, we would like to draw a conclusion on whether fiscal councils can become a global standard in the future.

\subsection{Methodology}

This analysis is based on the IMF's Fiscal Council Dataset. ${ }^{1}$ This database contains data for 39 FCs in 37 countries as at the end of 2016. In addition to general information (the official name of the fiscal council, the date of its establishment or profound reform), the database includes the main features of the individual FCs' competencies (specific duties and the means of influencing fiscal policy) and key institutional characteristics (independence, accountability requirements and human resources). The Variable Description see in Annex 1.

${ }^{1}$ Source: https://www.imf.org/external/np/fad/council/ 
Our methodology seeks to find relatively homogenous groups. Our test hypothesis is that, in a breakdown by EU and non-EU, fiscal councils have different characteristics. As a first step, we will use descriptive statistical methods. In the second step, a cluster analysis will be applied. The exact details of this analysis are based on the descriptive statistics, thus will be provided later, at the regarding part of the study (Cluster analysis). At the same time, we examine the institutional factors that may have led to the formation of different groups.

It is a general problem to manage in countries (Belgium and the Netherlands) where there are 2 operative fiscal councils, and thus the competencies and responsibilities are divided between the 2 organizations. As these are usually handled in a consolidated way ${ }^{2}$, this analysis includes 37 councils, and it is noted whenever the sample includes 39 councils.

\subsection{Descriptive statistics}

The structure adopted by Debrun et al. (2017) is followed for the data processing.

\section{General information}

The following indicators were analysed for each fiscal council: region (EU vs. non-EU); the year of foundation; the year of major changes to its mandate; if it is a parliamentary organization or a separate institution; which level of government is covered by its mandate.

The figure below shows an increase in the number of fiscal councils all over the world in response to the crisis. Note that the major part of this increase can be linked to the EU's mandatory regulation.

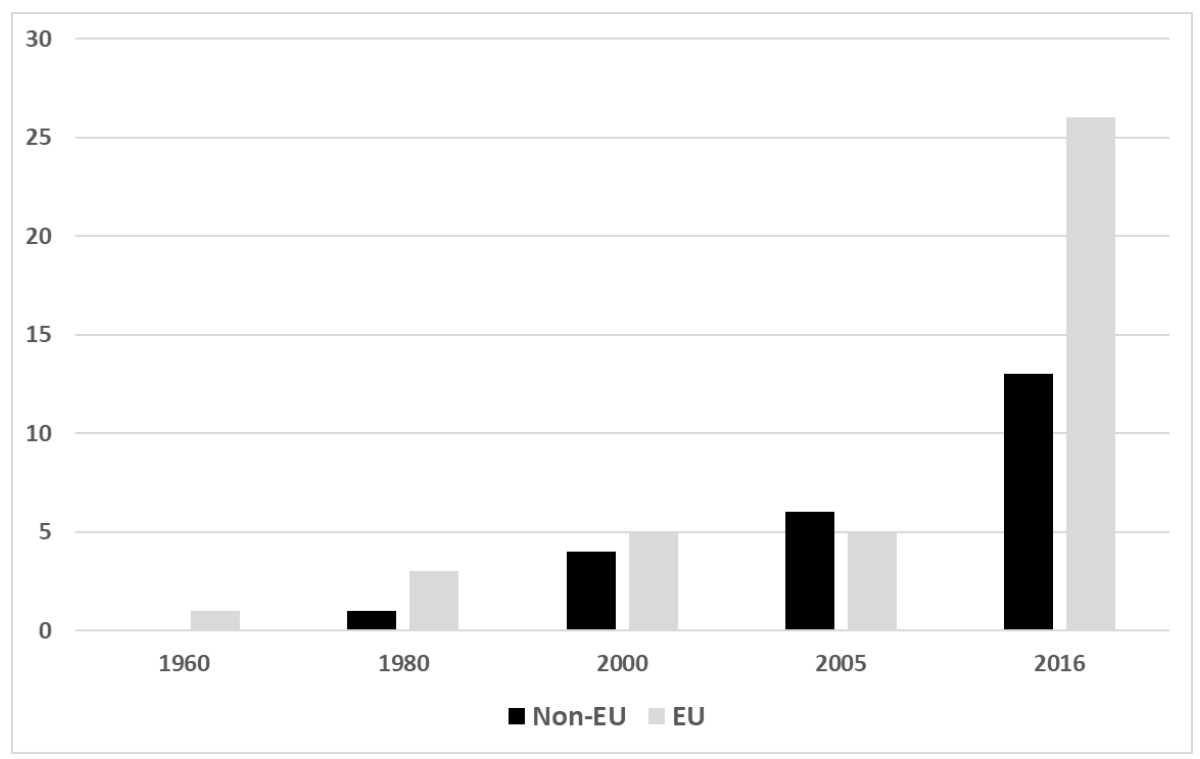

Figure 1. Number of fiscal councils

Source: IMF Fiscal Council Dataset

Note: The sample included 39 councils.

\footnotetext{
2 At least one of the two organization is performing the function under consideration.
} 
In the case of IFIs outside the EU, it is mainly the larger developed countries with federal structures (Australia, Canada and the USA) that have adopted these institutions and provided them with legal and operational independence. In addition to a federal structure, the establishment of IFIs may in many cases be clearly related to episodes of fiscal crisis. In the case of developing countries, IMF and OECD recommendations may have a significant role in the establishment of IFIs. The non-federal South Korea is a special case, as the National Assembly Budget Office was set up in 1994, and then it was re-organized in 2000, in response to the 1998 crisis, in the form of a Legislative Counselling Office and a Budget Policy Office, and made completely independent in 2003 under the name of the National Assembly Budget Office. In 1998-1999, as a result of a crisis, the federal state of Mexico also established its own institution under the name of the Center for Public Finance Studies. Naturally, the latter two are advisory bodies to parliaments, established to improve the fiscal authenticity of the given countries after the crises, and otherwise follow the organizational pattern of the U.S. Congressional Budget Office (Curristine et al., 2013). The Australian (2012) and South African (2014) Parliamentary Budget Offices were launched with similar motives and follow a similar example. In Chile, the fiscal council established in 2013 was reformed in 2018 to increase its independence. However, the fiscal discipline policy was started in Chile in 2001 by the Fiscal Responsibility Law, which required that the structural balance must have a 1\% surplus.

Major changes were made to the mandate in 11 of the 39 councils ( 7 of them in the EU). The overwhelming majority of the changes (8) were made after, and as a response to, the crisis.

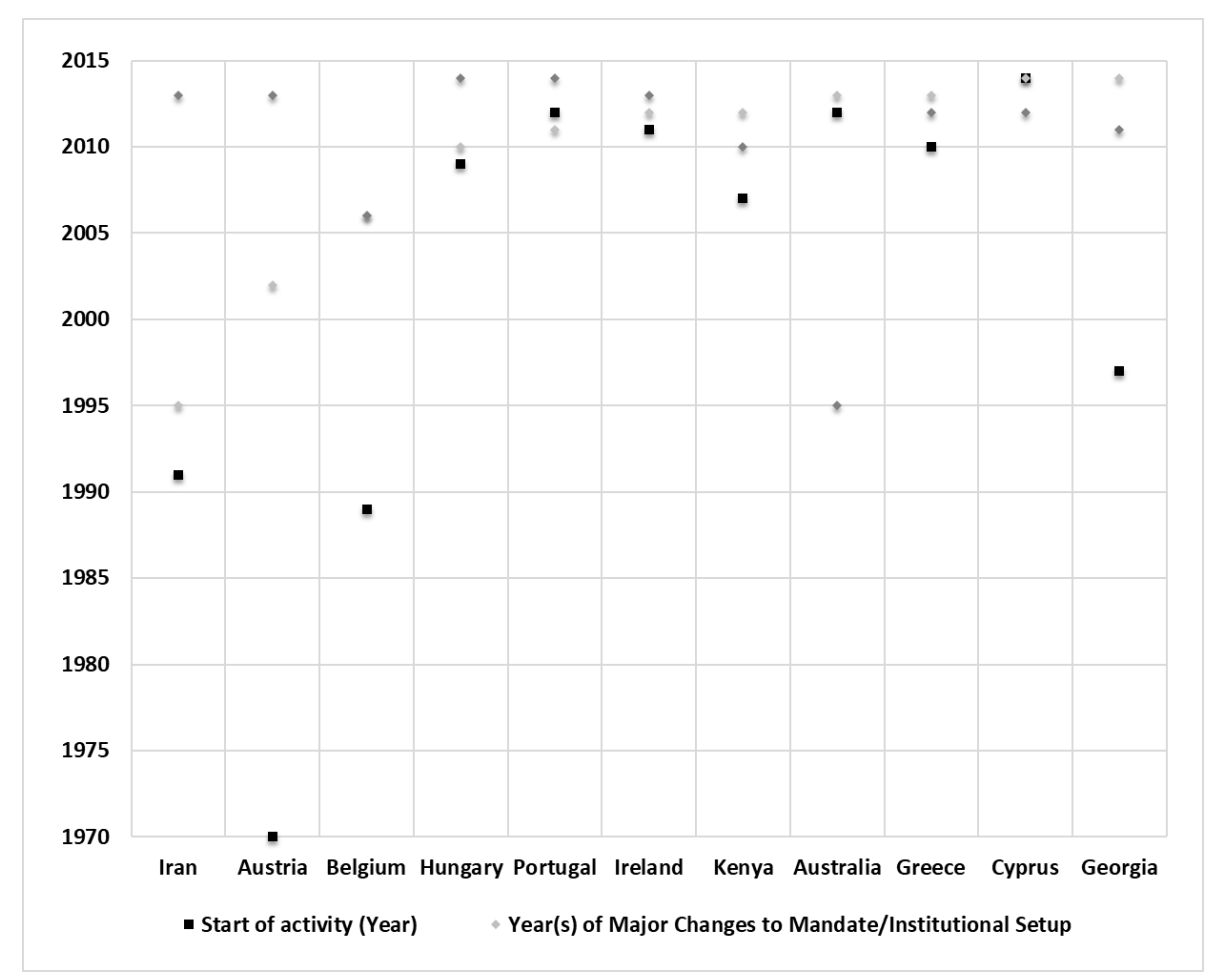

Figure 2. Year of Major Changes to Mandate/Institutional Setup

Source: IMF Fiscal Council Dataset

Note: The sample included 39 councils.

An important question is how this role appears institutionally: as a parliamentary fiscal advisory body independent of the government or as a body separate from parliament. As the IMF database does not include the latter breakdown, we have completed the database. Clearly, the typical institutional form in the 
EU is to have separate councils, while the practice outside the EU is mixed. Note that in the EU the national audit offices are assigned this role (in Lithuania and in Finland).

Table 1

Institutional form

\begin{tabular}{|l|c|c|}
\hline & EU & Non-EU \\
\hline Parliamentary organization & 2 & 8 \\
\hline $\begin{array}{l}\text { Organization separate } \\
\text { from Parliament }\end{array}$ & 24 & 5 \\
\hline
\end{tabular}

Source: IMF Fiscal Council Dataset

Note: In this case, a sample of 39 councils were divided.

Another important difference between the EU and non-EU groups is in the competences of the fiscal councils. Fiscal councils outside the EU usually (with the exception of 4) have mandates that only cover the central budget. In the EU they have a wider scope everywhere: they supervise the complete field of public finances.

\section{Key elements of the mandate}

Every IFI conducts positive and descriptive analyses. More than half of the IFIs are empowered to carry out normative analyses (i.e. recommend action to achieve the specific fiscal objectives). In non-EU countries, only 31 per cent of them has a normative competence, while in the EU Member States, this ratio is 67 per cent.

The most important activity IFIs perform is the predictive evaluation of the various aspects of fiscal developments. In an EU/non-EU breakdown, a significant difference is seen between the two groups.

Table 2

Key mandate elements

\begin{tabular}{|l|c|c|c|c|c|c|c|}
\hline & Forecasting & $\begin{array}{c}\text { Forecast } \\
\text { Assessment }\end{array}$ & Recommendations & $\begin{array}{c}\text { Long-term } \\
\text { sustainability }\end{array}$ & $\begin{array}{c}\text { Consistency } \\
\text { with } \\
\text { objectives }\end{array}$ & $\begin{array}{c}\text { Costing of } \\
\text { measures }\end{array}$ & $\begin{array}{c}\text { Monitoring } \\
\text { fiscal rules }\end{array}$ \\
\hline EU & $38 \%$ & $88 \%$ & $71 \%$ & $75 \%$ & $96 \%$ & $33 \%$ & $100 \%$ \\
\hline Non-EU & $62 \%$ & $69 \%$ & $77 \%$ & $38 \%$ & $54 \%$ & $62 \%$ & $31 \%$ \\
\hline
\end{tabular}

Source: IMF Fiscal Council Dataset

In the EU, every institution checks compliance with the various fiscal rules from a forward-looking perspective, including the evaluation of forecasts and longer-term sustainability. In non-EU countries, these aspects are considerably less significant, as the emphasis is basically on forecasts and on the assessment of the short- and/or long-term impacts of public finance actions.

With the exception of 6 institutions (2 IFIs in the EU, and 4 in developing non-EU countries), the majority conduct ex-post analyses. 


\section{Responsibilities and means}

Overall, it is clear that fiscal councils' direct impact on the budget process is currently less significant; they are basically considered as advisory bodies. However, in the EU Member States, they have a set of relatively more powerful instruments.

Table 3

Fiscal councils' direct impact on the budget process, $\%$

\begin{tabular}{|c|c|c|c|c|c|}
\hline & $\begin{array}{c}\text { Forecasts used } \\
\text { in the budget }\end{array}$ & $\begin{array}{c}\text { Binding } \\
\text { forecasts }\end{array}$ & $\begin{array}{c}\text { Comply or } \\
\text { explain }\end{array}$ & $\begin{array}{c}\text { Formal } \\
\text { consultation } \\
\text { or hearings }\end{array}$ & $\begin{array}{c}\text { Can stall the } \\
\text { budget process }\end{array}$ \\
\hline EU & $13 \%$ & $8 \%$ & $33 \%$ & $63 \%$ & $4 \%$ \\
\hline Non-EU & $8 \%$ & $0 \%$ & $0 \%$ & $23 \%$ & $0 \%$ \\
\hline
\end{tabular}

Source: IMF Fiscal Council Dataset

The other basic method they use is pressure through public opinion and the provision of objective information to the public about budgeting procedures throughout analysis. All but one of the fiscal councils make public (ex-post) reports. Six of the 37 fiscal councils did not have data available on the evaluation of media impact. ${ }^{3}$ According to the IMF's evaluation, 26 of 30 councils have a high media impact. In the EU Member States where data was available, 95 per cent of the IFIs had a significant media impact, and this ratio was 64 per cent in non-EU councils.

Table 4

Ratio of IFIs with a high media impact

\begin{tabular}{|c|c|c|c|}
\hline & High media impact & Low media impact & N.A. \\
\hline EU & $79 \%$ & $4 \%$ & $17 \%$ \\
\hline Non-EU & $54 \%$ & $31 \%$ & $15 \%$ \\
\hline
\end{tabular}

Source: IMF Fiscal Council Dataset

\section{Independence and accountability}

Independence can be considered from a legal and from an operational perspective. Legal independence is when the council's independence from political intervention is ensured by law or contract. However, de facto operational independence from politics may be implemented even in the absence of legal independence, due to the council's independent expertise (Vértesy, 2018). Note that in our opinion, in an undemocratic country (Iran) the term "independence" does not make any sense.

88 per cent of the EU IFIs can be considered legally and 81 per cent operationally independent. In non-EU countries, the corresponding ratios were 69 and 54 per cent, respectively. If the latter is further subdivided into developed and developing non-EU countries, we get two markedly different groups. Merely 33 per cent of IFIs in developing non-EU countries show operational independence, and if Iran is removed from this group, the ratio is only 22 per cent.

\footnotetext{
${ }^{3}$ The evaluation given by the IMF's experts reflects the number of publications and media references to reports published about the given council. In the case of EU Member States, the individual councils' self-assessments were also taken into account.
} 
Ratio of independence and impartiality

\begin{tabular}{|c|c|c|c|c|c|c|c|c|c|c|c|c|c|c|c|c|c|}
\hline $\begin{array}{l}\text { Name of the } \\
\text { country }\end{array}$ & & 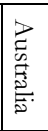 & 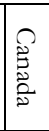 & $\begin{array}{c}c \\
\infty \\
D\end{array}$ & $\begin{array}{l}\text { क } \\
0 \\
0 \\
T \\
0 \\
0 \\
0 \\
0\end{array}$ & $\mathcal{P}_{0}$ & $\begin{array}{l}0 \\
0 \\
0 \\
0 \\
0 \\
\frac{0}{2}\end{array}$ & 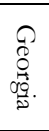 & $\overrightarrow{\mathrm{g}}$ & 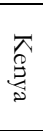 & .2. & $\overrightarrow{\mathscr{B}}$ & 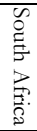 & 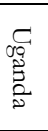 & $\begin{array}{c}\text { Developing } \\
\text { non-EU, } \\
\text { total, } \\
\%\end{array}$ & $\begin{array}{c}\text { Non-EU, } \\
\text { total, } \\
\%\end{array}$ & EU,\% \\
\hline \multirow{2}{*}{$\begin{array}{l}\text { Independence } \\
\text { / impartiality }\end{array}$} & Legal & 1 & 1 & 1 & 1 & 0 & 1 & 1 & 1 & 0 & 0 & 1 & 1 & 0 & $56 \%$ & $69 \%$ & $88 \%$ \\
\hline & $\begin{array}{c}\text { Operat } \\
\text { ional }\end{array}$ & 1 & 1 & 1 & 1 & 0 & 0 & 0 & 1 & 1 & 0 & 1 & 0 & 0 & $33 \%$ & $54 \%$ & $81 \%$ \\
\hline
\end{tabular}

Source: IMF Fiscal Council Dataset

Note: from the database of non-EU the following countries are considered as non-EU developing countries: Chile, Colombia, Georgia, Iran, Kenya, Mexico, Peru, South Africa, Uganda

The IMF database includes another three important elements of independence. In these cases, no significant difference is seen between EU and non-EU countries.

1. Safeguards on its own budget: currently, this component of independence is the least developed.

2. Most of the IFIs have the quality and quantity of staff appropriate to the responsibilities specified in its mandate, or they are entitled to establish such a staff.

3. Access to all material information is also mostly guaranteed by law.

Table 6

Additional three factors of institutional independence

\begin{tabular}{|c|c|c|}
\hline & Right to select staff & Access to information \\
\hline Safeguards on budget & Non-EU, \% & $77 \%$ \\
\hline $46 \%$ & $77 \%$ & $85 \%$ \\
\hline $58 \%$ & $81 \%$ & $\%$ \\
\hline
\end{tabular}

Source: IMF Fiscal Council Dataset

\section{Resources}

The IMF database characterizes the human resources related to IFI management by several groups of variables. One such group of variables relates to the composition and content of the IFI: the headcount, the number of years mandated, whether mandates are renewable or not, the members' backgrounds etc. This group has not been included in this analysis, as it is not considered a relevant indicator of our hypothesis.

Table 7

Powers to appoint and dismiss IFI leaders

\begin{tabular}{|r|c|c|c|c|c|}
\hline Type & EU & Non-EU & Type & EU & Non-EU \\
\hline Selected only by the government & $29 \%$ & $31 \%$ & Removed only by the government & $25 \%$ & $23 \%$ \\
\hline $\begin{array}{r}\text { The government jointly with } \\
\text { someone else }\end{array}$ & $21 \%$ & $8 \%$ & $\begin{array}{c}\text { The government jointly with } \\
\text { someone else }\end{array}$ & $4 \%$ & $0 \%$ \\
\hline Independent of the government & $46 \%$ & $54 \%$ & Independent of the government & $67 \%$ & $54 \%$ \\
\hline No data & $4 \%$ & $8 \%$ & No data & $4 \%$ & $23 \%$ \\
\hline
\end{tabular}

Source: IMF Fiscal Council Dataset, authors' calculation 
Approximately half of the IFIs can appoint their leaders independently of the government. In terms of dismissal, IFI leaders are slightly more protected from the government. The third group of variables shows the size of IFIs based on the number of non-executive employees.

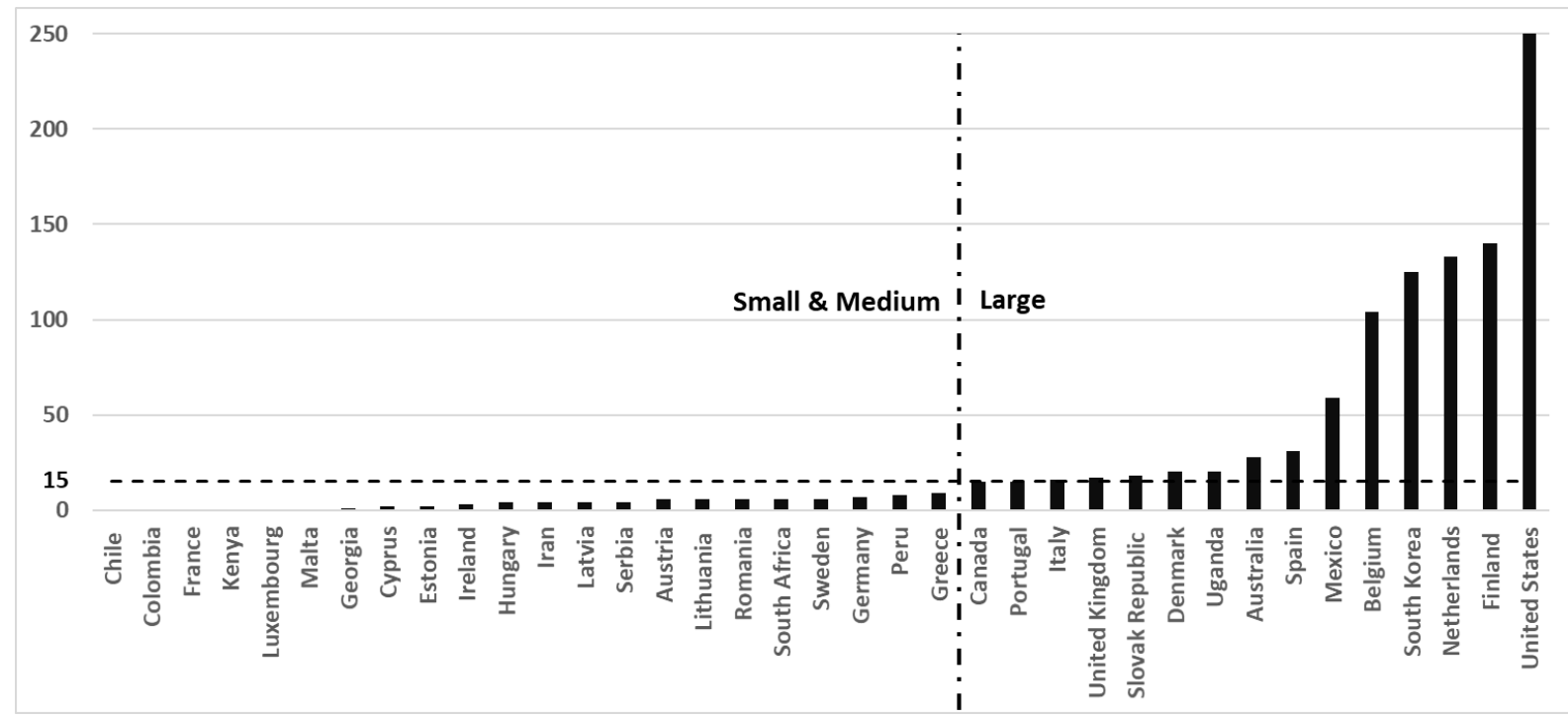

Figure 3. \# of Staff members.

Source: IMF Fiscal Council Dataset, authors' calculation

The above figures show that the majority of IFIs are small in size: those employing more than 15 persons are already considered large (there are 15 of them). For this reason, in the cluster analysis, the sample is divided into two: small and medium-sized/large institutions (with an employee headcount exceeding 15).

\section{Cluster analysis}

This research uses the method of hierarchical cluster analysis, i.e. the classification of countries in different groups called clusters. The Euclidean square-distance indicator is selected to determine the distance between countries. Ward's method ${ }^{4}$ is used for classification, as it reduces dispersion in groups and increases their homogeneity. For the calculation, we used Orange data mining software.

The explanatory variables are those detailed under the title "Descriptive statistics". Two constant variables (the year of establishment and the year of a major change) are omitted from the analysis for technical reasons (as during the cluster analysis they cannot be effectively used together with discrete variables).

Each of the other variables is transformed into a discrete numerical value (which may be 0 or 1 ). The absence of data is marked by a separate variable ( 0 or 1$)$. For example, the following 3 variables are defined for the selection of Governing / High-level Management Members: "Selected only by Government", "Selected not only by Government", and "Selected by n.a.". If any data is missing, the last variable may be 1 and the others may be 0 . Based on the above, we have 34 variables for each country. Variables represent the status of councils as of 2016.

\footnotetext{
${ }^{4}$ The dissimilarity between two clusters is computed as the increase in the "error sum of squares" (ESS) after fusing two clusters into a single cluster. Ward's method chooses the successive clustering steps to minimize the increase in ESS at each step.
} 
The number of variables is too high for our cluster analysis, since it results in too many dimensions comparing with the number of countries. We deceased the number of dimensions in two ways. Firstly, we omitted the highly correlated $(|\operatorname{corr}|>0,6)$ variables (6). Please see the correlation table in Annex 2. Secondly we combined the variable using mean of certain group of variables:

- Key elements of the mandate is the combined variable of the following variables (7): normative analysis, recommendations, forecasting, forecast assessment, long-term sustainability, consistency, and costing of measures.

- Soft means is the combination of the following variables (4): ex-post analysis, public report, high media impact, and high media impact n.a.,

- Hard means includes the followings (4): forecasts used in budget, comply or explain, consultation or hearing, and 'stall the budget process'.

- Independence covers a wide range of variables (11): legal independence, operational independence, budget safeguard, select staff. select staff n.a., access to inform, selected only by government, selected not only by government, dismissal not only by government, dismissal by n.a.

Size, parliamentary organization or a separate institution; and coverage (central / general government) were not combined. In this way we got 7 variables. The results are depicted in a dendrogram.

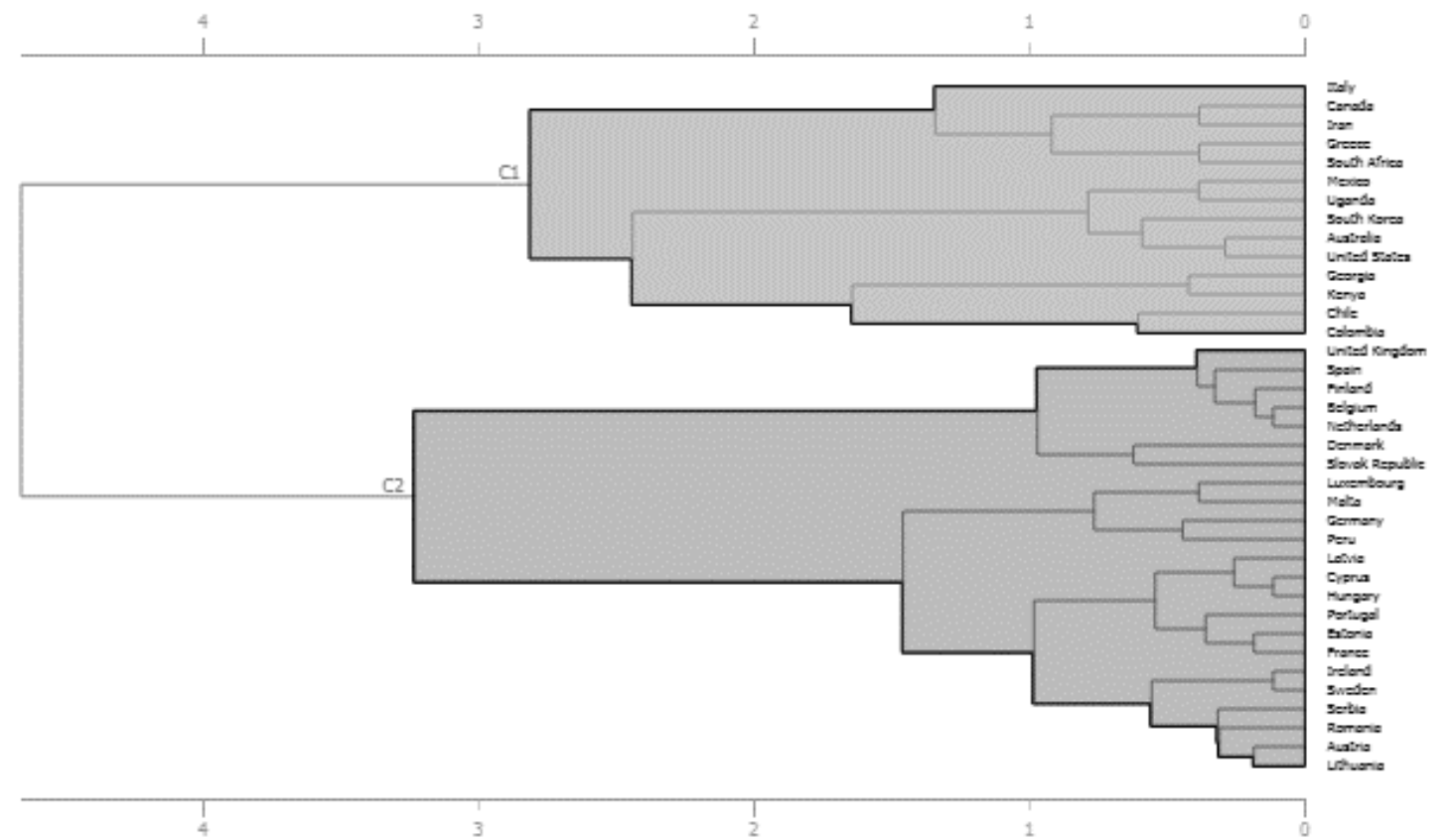

Figure 4. Dendrogram

Source: IMF Fiscal Council Dataset, authors' calculation

The above two figures clearly show the two main clusters: in practice, an EU vs. non-EU breakdown. The cluster analysis includes Chile, Colombia and Peru in the EU group. Greece and Italy are transferred to the non-EU group. As we can also observe, the countries which adopted the US-model were in the same clusters. 
We prepared a Silhouette Plot graphically representing the consistency within clusters of data and assessing clusters' quality. The silhouette score is a measure of how similar a country is to its own cluster in comparison to other cluster. The silhouette ranges from -1 to +1 . Silhouette coefficients +1 indicate that the country is far away from the neighbouring cluster (perfectly matched). A value of 0 indicates that the sample is on or very close to the decision boundary between two neighbouring cluster. In total the quality of our cluster analysis could be classified as moderate.

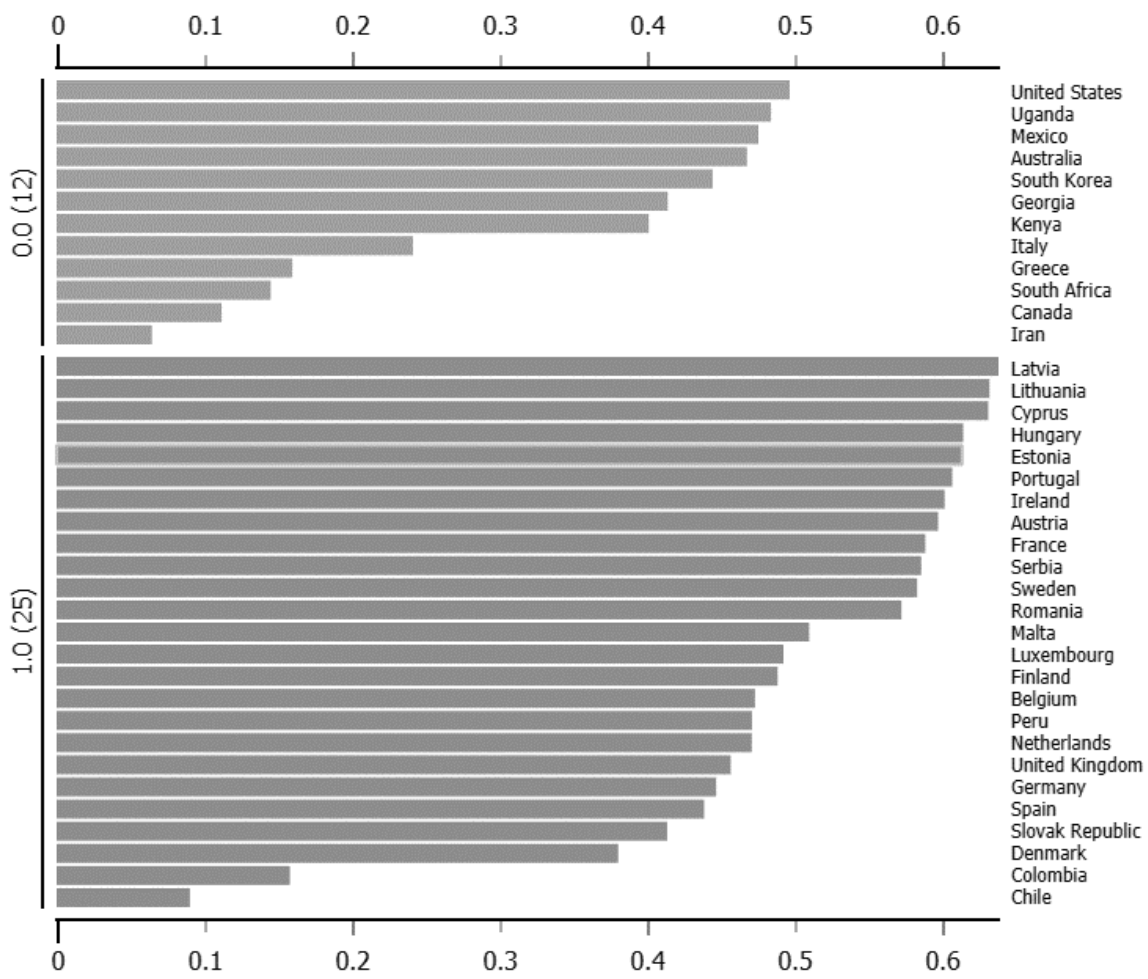

Figure 5. Silhouette Plot

Source: IMF Fiscal Council Dataset, authors' calculation

\section{CONCLUSION}

Much has been done nationally and internationally in the interests of improving the regulation and methodology of fiscal supervision, but ex-post government verification, rules-based budgeting and fiscal controlling cannot arrest deficit and sovereign debt. This is why independent fiscal institutions (IFIs) have been set up in numerous countries.

The relevant literature emphasizes the heterogeneity of fiscal councils. In contrast, our cluster analysis of fiscal councils corroborates the hypothesis that the features of fiscal councils in EU and non-EU states can be clearly separated.

The separation between these two groups can best be grasped by the following characteristics. With respect to the institutional form, in the EU it is typically a body separate from the parliament, while outside the EU there are considerably more IFIs that may be linked to the parliament.

In terms of the key mandate elements, in the EU every institution checks compliance with the various fiscal rules from a forward-looking perspective, while in non-EU countries these mandates have considerably less weight. In the latter, the stress falls primarily on fiscal forecasts and on the assessment of the short- and/or long-term impacts of major public finance actions. 
In an analysis of influence on fiscal processes, it can be established that currently, fiscal councils' direct impact on the budget process is less significant; they are basically considered as advisory bodies. Nevertheless, in the EU Member States, they have a set of relatively more powerful instruments in this area. Practically everywhere (95\%) in the EU, IFIs have an indirect impact on the budget process, through the media, while not all non-EU IFIs have it (64\%). Most IFIs have both legal and operational independence in the EU, while this ratio is also lower among non-EU IFIs. In non-EU developing countries, it is particularly low.

In our opinion, one of the main causes of divergence between IFIs in the EU and in non-EU countries is that, in the EU, the strengthening of IFIs is supported by an increase in fiscal cohesion and the longerterm objective of the fiscal union. This process is accelerated by the common European regulation and other integration policies (common crisis management mechanism, banking and capital market union). The current anti-EU movements in Europe are not strong enough to stop the further developments.

In contrast, outside the EU the establishment of IFIs is triggered by the federal organization, on the one hand, and the need to respond to the reduction of fiscal authenticity caused by crises, on the other hand. The IMF and the OECD have also contributed to the latter. An additional factor is the adoption of similar patterns (USA) operative outside the EU.

For this reason, in normal circumstances central government politicians in non-EU countries may not be expected to voluntarily give up discretional fiscal policy or, even if they adopt a rules-based fiscal policy, to "voluntarily" establish genuinely independent supervisory institutions. Based on the above, IFIs can very much be considered a European solution rather than the evolution of a new global standard. The main novelty and research contribution of our study to the theory are that the findings of our analysis underpin the conjecture that these institutions are not formed as a fiscal-economic necessity, but rather as part of a broader intention for economic integration or a special political deal. 


\section{ANNEX 1. VARIABLE DESCRIPTION}

\section{General information}

1. Region: EU or non-EU;

2. Year of foundation;

3. Year of major changes to its mandate according to IMF assessment;

4. Parliamentary organization or a separate institution;

5. Level of government is covered by its mandate: central / general government.

\section{Key elements of the mandate}

6. Normative analysis: if the council performs normative analyses;

7. Recommendations: if the council performs normative analysis or giving recommendations;

8. Forecasting: if the council is mandated to produce macroeconomic forecasts for the budget;

9. Forecast assessment: if the council is mandated to assess macroeconomic forecasts used for budgetary projections;

10. Long-term sustainability is defined as the long-term forecast of government balance and debt level;

11. Consistency with objectives is defined as the assessment of government budgetary and fiscal performance in relation to fiscal objectives and strategic priorities;

12. Costing of measures is defined as the quantification of either short-term or long-term effects, or both, of measures and reforms;

13. Monitoring of fiscal rules: if the council is mandated to monitor compliance with numerical fiscal rules.

\section{Responsibilities and means}

14. Forecasts used in the budget: the council's forecasts are used in the budget.

15. Binding forecasts: the council's forecasts must be used in the budget.

16. Comply or explain: by default, the council's forecasts must be used in the budget. The deviation is allowed, but justification is required.

17. Formal consultation or hearings: the government is officially obliged to consult the council and/or the parliament must hear the fiscal council in the course of the budget process.

18. Can stall the budget process: the council is authorized by law to stop the budget process.

19. Ex-post analysis: ex-post analysis of fiscal processes.

20. Public report preparation.

21. High Media Impact: IMF's assessment on media impact of the given council. All but one of the fiscal councils make public reports.

22. High Media Impact n.a.: cases when IMF's assessment is not available.

\section{Independence and Accountability}

23. Legal independence: if the council's independence from political interference is guaranteed by law.

24. Operational independence: de facto operational independence from politics, the council might very well operate as an independent body because its analysis reflects its expertise.

25. Safeguards on budget: if the budget the council is (i) set by the central bank, (ii) part of the overall budget, but protected from executive decisions), (iii) subject to any other guarantee commonly granted to independent institutions, such as regulators.

26. Staff in line with duties: the council has the quality and quantity of staff appropriate to the responsibilities specified in its mandate, or it is entitled to establish such a staff.

27. Staff in line with duties n.a.: when data is not available on staffing. 
28. Access to information: the council is guaranteed in legislation to have full access to all relevant information in a timely manner.

\section{Resources}

29. Selection of high-level staff only by the Government: whether the council high-level staff is selected only by the government.

30. Selection of high-level staff not only by the Government: when the council high-level staff is selected not only by the government.

31. Selection of high-level staff n.a.: when data on the selection is not available.

32. Dismissal of high-level staff only by the Government: whether the council high-level staff can be dismissed only by the government.

33. Dismissal of high-level staff not only by the Government: whether the council high-level staff can be dismissed not only by the government.

34. Dismissal of high-level staff n.a.: when data on the dismissal is not available.

35. Size of the council: the number of non-executive employees.

36. Size of the council n.a.: when data on the size is not available. 
ANNEX 2. CORRELATION MATRIX

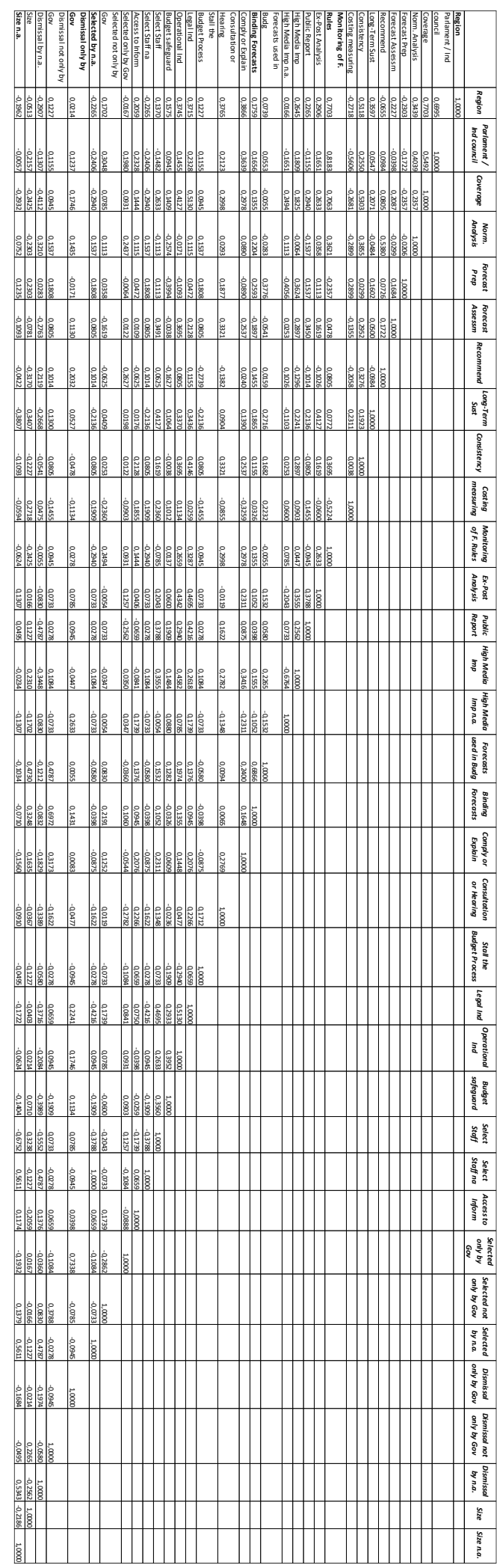


ACKNOWLEDGEMENT: In A Part of Csaba Lentner (Coresponding Author), This Study was Supported by PADS, Hungarian National Bank Foundation

\section{REFERENCES}

Acharya, V.V., \& Steffen S. (2017). The Importance of a Banking Union and Fiscal Union for a Capital Markets Union. 2017 Fellowship Initiative Papers. European https://ec.europa.eu/info/sites/info/files/dp_062_en.pdf

Beetsma, R., \& Debrun, X. (2016). Debunking 'fiscal alchemy: The role of fiscal councils'. VoxEU Article, http://voxeu.org/article/debunking-fiscal-alchemy-role-fiscal-councils

Berger, H., Dell'Ariccia, G., \& Obstfeld, M. (2018). Revisiting the Economic Case for Fiscal Union in the Euro Area. IMF Departmental Paper No.18/03. https://www.imf.org/en/Publications/Departmental-Papers-PolicyPapers/Issues/2018/02/20/Revisiting-the-Economic-Case-for-Fiscal-Union-in-the-Euro-Area-45611

Blinder, A. S. (1997). Is Government Too Political? Foreign Affairs, November/December 1997, pp. 115-127.

Calmfors, L., \& Wren-Lewis, S. (2011). What should fiscally do? The University of Oxford. Discussion Paper series. https://www.economics.ox.ac.uk/department-of-economics-discussion-paper-series/what-should-fiscalcouncils-do

Curristine, T., Harris, J., \& Seiwald, J. (2013). Case studies of fiscal councils-functions and impact. IMF. https://www.imf.org/external/np/pp/eng/2013/071613a.pdf

Debrun, X., \& Kumar, M.S. (2007). Fiscal Rules, Fiscal Councils and All That: Commitment Devices, Signalling Tools or Smokescreens? in Fiscal Policy: Current Issues and Challenges, Banca d'Italiahttps://www.bancaditalia.it/pubblicazioni/altri-atti-convegni/2007-fiscalpolicy/Debrun_Kumar.pdf?language_id =1

Debrun, X., \& Kinda, T. (2014). Strengthening Post-Crisis Fiscal Credibility: Fiscal Councils on the Rise - A New Dataset, IMF Working Paper, WP/14/58.

Debrun, X., Zhang, X., \& Lledó, V. (2017). The Fiscal Council Dataset: A Primer to the 2016 Vintage. Remitting from https://www.imf.org/external/np/fad/council/pdf/note.pdf

European Commission (2003). Public finances in EMU. European Economy Reports and Studies. http:/ /ec.europa.eu/economy_finance/publications/pages/publication473_en.pdf

European Fiscal Board (2018). Annual Report 2017. https://ec.europa.eu/info/sites/info/files/2017_efb_annual_report_en_0.pdf

Fischer, S. (1995). Central-Bank Independence Revisited. The American Economic Review, Papers and Proceedings, 85(2), 201 206.

Gersl, A., Jasova, M., \& Zápal, J. (2014). Fiscal Councils and Economic Volatility. Crech Journal of Economics and Finance, 64(3).

Gilbert, N. D., \& de Jong J.F.M. (2017). Do European fiscal rules induce a bias in fiscal forecasts? Evidence from the Stability and Growth Pact. Public Choice.

Herzog, B. (2018). Reforming the Eurozone: Assessment of the Reform Package by the European Commission Treating Symptoms or Root Causes?. Economics and Sociology, 11(3), 59-77.

IMF (2013). The functions and impact of fiscal councils. https://www.imf.org/external/np/pp/eng/2013/071613.pdf

Jiroudková, A., Rovná, L. A., Strielkowski, W., \& Šlosarčík, I. (2015). EU Accession, Transition and Further Integration for the Countries of Central and Eastern Europe. Economics and Sociology, 8(2), 11-25.

Kopits, G. (2016). The Case for an Independent Fiscal Institution in Japan. IMF Working Paper WP/16/156. https://www.imf.org/external/pubs/ft/wp/2016/wp16156.pdf

Larch, M., \& Braendle, T. (2018). Independent Fiscal Councils: Neglected Siblings of Independent Central Banks? An EU Perspective. Journal of Common Market Studies, 56(2), 267-283.

Musgrave, R. A. (1959). The theory of public finance: a study in public economy, New York, McGraw-Hill.

OECD (2014). Recommendation of the Council on Principles for Independent Fiscal Institutions. https://www.oecd.org/gov/budgeting/OECD-Recommendation-on-Principles-for-Independent-FiscalInstitutions.pdf 
Thirion, G. (2017). European Fiscal Union: Economic rationale and design challenges. CEPS Working Document. No 2017/01, January 2017. https://www.ceps.eu/publications/european-fiscal-union-economic-rationale-and-designchallenges

Vértesy, L. (2018). Macroeconomic legal trends in the EU11 countries. in Public Governance, Administration and Finances Law Review, 2018/I, 3.

Wyplosz, C. (2002). Fiscal Policy: Institutions vs. Rules. HEI Working Paper No: 03/2002 http://repec.graduateinstitute.ch/pdfs/Working_papers/HEIWP03-2002.pdf 